\title{
Liter per Picogram per Minute
}

National Cancer Institute

\section{Source}

National Cancer Institute. Liter per Picogram per Minute. NCI Thesaurus. Code C85695.

Liters per picogram per minute. 